\title{
Pemakaian Bahasa Jawa di Provinsi Lampung Bedasar Data Sensus Penduduk 2010
}

\author{
Suyanto dan Mujid FA \\ Fakultas Ilmu Budaya Universitas Diponegoro \\ suyanto@live.undip.ac.id dan moejid70@gmail.com
}

\begin{abstract}
The study of this language is macro by using data from the census of Indonesian population 2010. The study included (a) the number of Javanese speakers in Lampung in 2010, (b) the factor of Javanese distribution in Lampung in 2010, and (c) and the influence Javanese in Lampung. Obtaining data using the method refer. Data analysis used descriptive statistical analysis using single frequency distribution table and continued with categorical analysis and interpreted theoretically various prominent phenomena. The results showed that spatially the population in Lampung more use of Javanese language than Lampung. In addition, the population proportion of migration Java population is more than the total population of Lampung. This is closely related to the migration program of the Javanese population that had begun since the Dutch colonial era up to the Soeharto era.
\end{abstract}

Keywords: speakers, Javanese, distribution, migration, Lampung.

\section{Intisari}

Studi bahasa ini bersifat makro dengan menggunakan data hasil sensus penduduk Indonesia. Studi ini bertujuan mengetahui migrasi bahasa Jawa di Lampung tahun 2010 dengan menggunakan data Sensus Penduduk 2010. Studi mencakup (a) jumlah penutur bahasa Jawa di Lampung tahun 2010, (b) faktor persebaran bahasa Jawa di Lampung tahun 2010, dan (c) dan pengaruh bahasa Jawa di Lampung. Pemerolehan data menggunakan metode simak. Analisis data menggunakan analisis statistik deskriptif dengan menggunakan tabel distribusi frekuensi tunggal dan dilanjutkan analisis kategoris dan memaknai secara teoretis berbagai fenomena yang menonjol. Hasil penelitian menunjukkan bahwa secara spasial penduduk di lampung lebih banyak menggunakan bahasa Jawa daripada bahasa Lampung. Selain itu, secara kependudukan proporsi migrasipendudukJawamemang lebih banyak dibanding dengan jumlah penduduk Lampung. Hal ini berkaitan erat dengan program migrasi penduduk Jawa yang telah dimulai sejak zaman kolonial Belanda hingga zaman Soeharto.

Kata kunci: penutur, bahasa Jawa, distribusi, migrasi, Lampung. 


\section{Pendahuluan}

Indonesia merupakan Negara multietnik yang dengan sendirinya dalam kondisi multibahasa. Berdasar catatan Sensus Penduduk 2010, Indonesia memiliki 1.211 bahasa. Dari jumlah tersebut, 1.158 bahasa di antaranya merupakan bahasa ibu (istilah yang dipergunakan oleh Biro Pusat Statistik (BPS) adalah bahasa daerah). Sementara itu, data jumlah bahasa ibu di Indonesia sampai 2005 menurut Kushartanti dan Lauder (2005) sebanyak 726. Dari 1.211 bahasa yang riil dipergunakan dalam komunikasi sehari-hari di dalam rumah tangga, bahasa Jawa menunjukkan dominasi jumlah penuturnya, yakni mencapai 31,79 persen, dan urutan kedua dan ketiga adalah bahasa Indonesia dan Sunda, masingmasing 19,94 persen dan 15,14 persen (BPS, 2010). Karena itu, Borin (2009) menempatkan bahasa Jawa dalam peringkat 12 bahasa ibu dengan jumlah penutur terbanyak di dunia. Akan tetapi, dalam perkembangan waktu menunjukkan bahwa penduduk Indonesia cenderung beralih memilih bahasa Indonesia sebagai pengantar sehari-hari dalam ranah rumah tangga, dan sudah barang tentu pada ranah publik. Data menunjukkan bahwa penduduk Indonesia yang sekaligus sebagai penutur bahasa Indonesia dalam komunikasi sehari-hari pada tahun 1990 sebesar 10,73 persen dan naik hampir dua kali lipat pada 2010 menjadi 19,94 persen. Data selengkapnya tentang persentase jumlah penutur bahasa-bahasa di Indonesia ditunjukkan dalam gambar di bawah ini. 


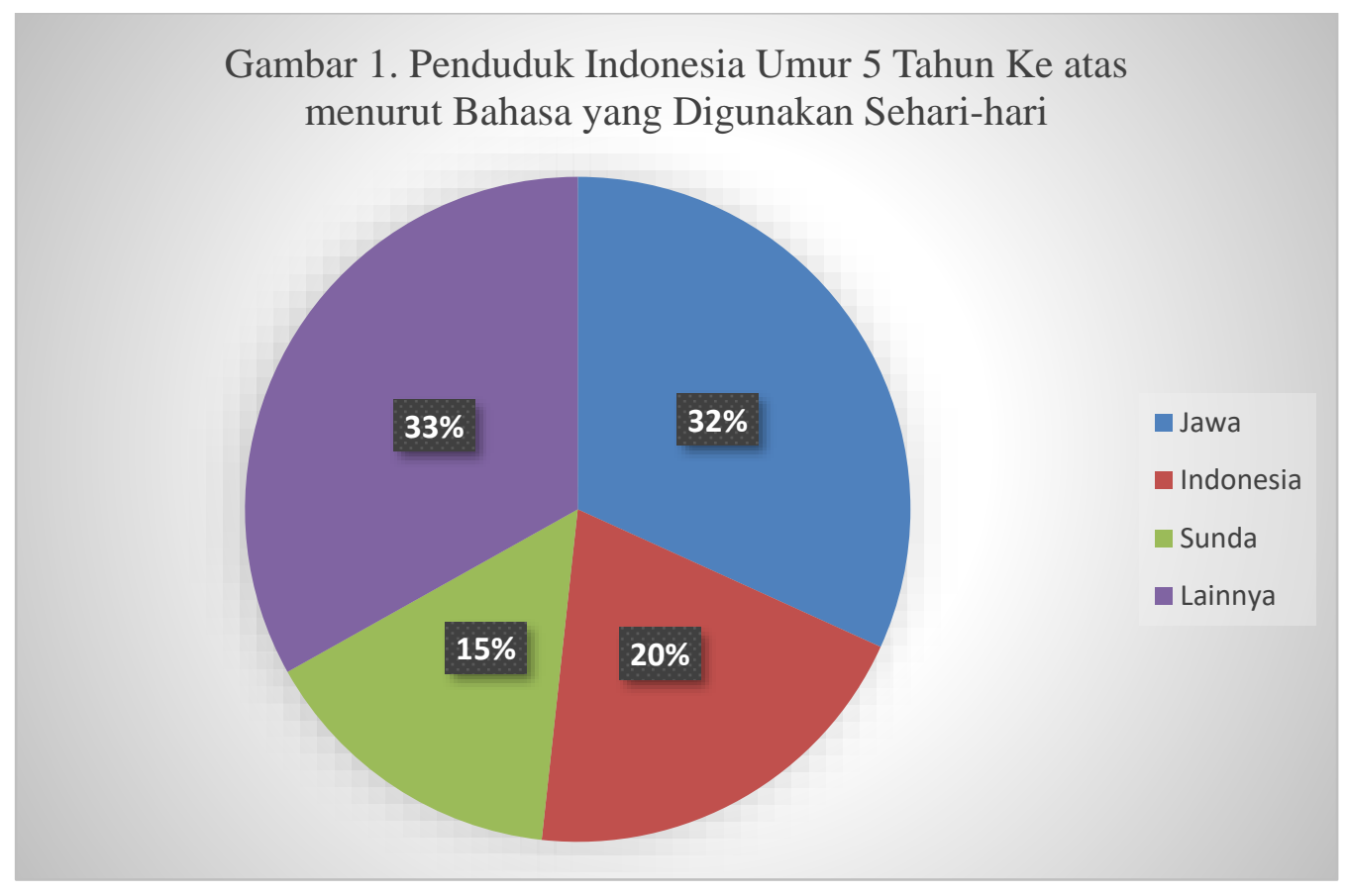

Sumber: BPS, 2011.

Bahasa Jawa merupakan bahasa ibu etnik Jawa yang mendiami wilayah Jawa Tengah dan Jawa Timur, kecali Madura. Akan tetapi, karena jumlah penutur bahasa Jawa cukup dominan (32 persen dari seluruh penduduk Indonesia) sehingga pemakaian bahasa Jawa dalam komunikasi sehari-hari menjadi tidak terbatas di Jawa Tengah dan Jawa Timur. Satu wilayah kantong bahasa Jawa utama di Indonesia di luar Jawa Tengah dan Jawa Timur adalah Provinsi Lampung (BPS, 2010). Penutur bahasa Jawa di Lampung merupakan urutan ketiga terbesar di Indonesia setelah Jawa Tengah dan Jawa Timur. Hal ini tidak lepas dari pengaruh faktor migrasi penutur bahasa Jawa ke berbagai pulau di Indonesia, termasuk ke Lampung.

Dalam studi demografilinguistik, migrasi penutur bahasa merupakan salah satu variabel utama. Dengan mengadaptasi studi demografi (Mantra, 2015), demografilinguistik memfokuskan kajiannya pada struktur dan proses demografilinguistik di suatu wilayah tertentu. Struktur demografilinguistik meliputi jumlah, komposisi, dan persebaran penutur bahasa dalam satu wilayah tertentu. Sementara itu, proses demografilinguistik meliputi kelahiran, kematian, dan migrasi penutur bahasa. Struktur bersifat statis sedangkan proses bersifat dinamis (Suyanto, 2016). 
Dalam paper ini, kajian difokuskan pada aspek struktur demografilinguistik yang dikaitkan dengan salah satu faktor proses demografilinguistik yaitu migrasi penutur bahasa, dalam hal ini penutur bahasa Jawake Lampung.Kajian demografilinguistik sampai saat ini nyaris belum dilakukan oleh para linguis Indonesia. Hal ini disebabkan istilah ini sebagai sebuah disiplin baru dalam pengkajian bahasa belum populer. Tulisan Suyanto (2011) misalnya, yang merupakan awal kajian demografilinguistik di Indonesia, masih menyebutnya dengan istilah sosiolinguistik dengan pendekatan makro tentang jumlah penutur bahasa (Indonesia) yang menggunakan data sekunder (data Sensus Penduduk (SP) 1980). Tulisan tersebut mengkaji jumlah penutur bahasa Indonesia dikaitkan dengan variabel tempat tinggal (desa-kota dan pulau), jenis kelamin (jender), dan tingkat pendidikan. Studi tersebut menjelaskan bahwa penutur bahasa di daerah perkotaan lebih mampu menggunakan bahasa Indonesia daripada penuturbahasa di pedesaan. Sementara itu, distribusi secara kepulauan penutur bahasa Indonesia didominasi oleh pulau Sumatera, walaupun secara absolut (jumlah), penutur bahasa Indonesia terbanyak tinggal di pulau Jawa. Dari segi jenis kelamin, komposisi penutur bahasa Indonesia lebih didominasi oleh laki-laki daripada perempuan. Hal ini berkaitan erat dengan akses dalam memeroleh pendidikan dan migrasi pada tahun 1970-1980 yang lebih luas bagi laki-laki (Suyanto, 2011).

Studi yang lebih awal lagi dilakukan olehSamuel (2008) yang memfokuskan pada dinamika jumlah penutur bahasa Indonesia sejak 1928 hingga 1990, kecuali SP 1980. Menurutnya, jumlah penutur bahasa Indonesia tahun 1928, 1971, dan 1990 masing-masing 4,9 persen, 40,8 persen, dan 75,0 persen (2008:82). Perkembangan jumlah penutur bahasa Indonesia dari waktu ke waktu yang sangat signifikan itu dikatakannya sebagai " keajaiban bahasa Indonesia".

Dalam skala global, Lars Borin (2009), Musgrave dan John Hajek (2010), dan Borbely (2000) telah melakukan studi bahasa dalam skala makro. Studi Lars Borin (2009)tentang pergeseran, perkembangan, dan kepunahan bahasa di dunia dikaitkan dengan teknologi informasi, media massa, dan kitab 
agama tertentu; Musgrave dan John Hajek (2010) tentang pemertahanan bahasabahasa etnis Sudan bagi migran yang berasal dari Sudan di Melbourne, dan Borbely (2000) tentang proses dan faktor pengaruh pemertahanan bahasa etnis minoritas migran Romania di Hungaria (Amin dan Suyanto, 2017).

\section{Metode Penelitian}

Studi ini menggunakan sumber data Sensus Penduduk 2010 yang dilaporkan dalam bagian tersendiri dengan judul Kewarganegaraan, Suku Bangsa, Agama dan Bahasa Sehari-hari Penduduk Indonesia: Hasil Sensus Penduduk 2010 (BPS, 2011). Dalam laporan tersebut disajikan data tentang bahasa yang dipakai sehari-harisebagai variabel statis demografilinguistik (distribusi dan jumlah penutur bahasa), terutama di Lampung. Menurut BPS 2010, bahasa sehari-hariadalah "bahasa yang biasa dipakai dalam komunikasi di rumah antarsesama anggota rumah tangga".

Data itu diperoleh menggunakan metode simak (Sudaryanto, 1988; Kesuma, 2007), yakni dengan menyimak dan mengamati data yang relevan dengan tujuan studi ini. Penyimakan difokuskan pada jumlah penutur bahasa Jawa dan selain bahasa Jawa di Lampung, komposisi penutur bahasa Jawa di Lampung terhadap penutur bahasa Jawa secara nasional (Indonesia), dan jumlah penduduk di Provinsi Lampung menurut suku bangsa dan kewarganegaraan.

Analisis data menggunakan statistik deskriptif, terutama distribusi frekuensi tunggal dan silang. Tahap selanjutnya yakni analisis kategoris dan memaknai gejala yang ada secara teoretis dengan teori demografilinguistik.

\section{Jumlah Penutur Bahasa Jawa dan Etnis Di Lampung Jumlah Penutur Bahasa Jawa di Lampung Tahun 2010}

Secara keseluruhan, jumlah penduduk di Provinsi Lampung berjumlah 7.581.948 jiwa. Penduduk sejumlah itu, 9,71 persen (728.817 jiwa) di antaranya berusia lima tahun atau di bawahnya. Dengan demikian, penduduk di Provinsi Lampung yang berumur lima tahun atau lebih berjumlah 6.853.131 (90,39 persen). Jumlah itulah yang dijadikan dasar penentuan dan perhitungan jumlah 
penutur bahasa. Penentuan umur ini berdasar asumsi bahwa anak umur di bawah lima tahun masih dalam tahap pemerolehan bahasa.

Berdasarkan data SP 2010, penduduk di Provinsi Lampung lebih dari 55 persen sebagai penutur bahasa Jawa dalam komunikasi sehari-hari. Sementara itu, bahasa Indonesia sebagai sarana komunikasi sehari-hari menempati urutan kedua $(22,74$ persen) dan urutan ketiga adalah bahasa Sunda yang hampir delapan persen dari kesekluruhan jumlah penduduk Lampung. Dalam tabel tersebut tidak secara eksplisit dimunculkan jumlah penutur bahasa Lampung karena secara nasional jumlah penutur bahasa Lampung tidak signifikan. Namun, dalam tabel tersebut diinformasikan bahwa jumlah penutur bahasa "lain" mencapai 13 persen lebih. Jumlah itulah yang sebenarnya merupakan penutur bahasa Lampung. Data tersebut dapat ditriangulasi menggunakan jumlah penduduk Lampung berdasar asal suku bangsa. Data SP 2010 menunjukkan bahwa jumlah penduduk Lampung yang berasal dari suku Lampung sebanyak 13,56 persen, sedangkan penutur bahasa lain sebesar 13,66 persen. Data selengkapnya jumlah penutur bahasa yang tinggal di Provinsi Lampung disajikan di bawah ini.

Tabel 1 Jumlah Penduduk Lampung bedasar Pemakaian Bahasa sehari-hari di Rumah (Bahasa Ibu)

\begin{tabular}{|c|l|r|r|}
\hline No & Bahasa Yang Digunakan & Jumlah & \multicolumn{1}{c|}{ Persen } \\
\hline 1 & Jawa & 3791368 & 55.32 \\
\hline 2 & Indonesia & 1558617 & 22.74 \\
\hline 3 & Sunda & 526678 & 7.69 \\
\hline 4 & Melayu & 16233 & 0.24 \\
\hline 5 & Madura & 968 & 0.01 \\
\hline 6 & Minangkabau & 5785 & 0.08 \\
\hline 7 & Banjar & 10 & 0.00 \\
\hline 8 & Bugis & 5760 & 0.08 \\
\hline 9 & Tidak Jawab & 11673 & 0.17 \\
\hline 10 & Lainnya & 936039 & 13.66 \\
\hline & Jumlah & 6853131 & 100.00 \\
\hline
\end{tabular}

Sumber: BPS, 2011.

\section{Jumlah Penduduk Lampung berdasarkan Asal Suku Bangsa}


Berdasar etnisitas, penduduk Provinsi Lampung hampir 65 persen adalah etnis Jawa. Penduduk etnis asli Lampung di tanah kelahirannya hanya 13,56 persen. Kelompok etnis ketiga terbesar yang tinggal di Lampung adalah Sunda sebanyak 9,61 persen dan disusul etnis dari Sumatra Selatan pada posisi keempat sebesar 5,40 persen. Kenyataan tersebut di satu sisi menunjukkan tingginya penghargaan atas multikulturalisme namun di sisi yang lain juga merupakan tekanan atas hidup dan berkembangnya budaya lokal asli Lampung karena didominasi oleh budaya Jawa.Selengkapnya jumlah penduduk Provinsi Lampung berdasar asal suku bangsa dipaparkan dalam tabel di bawah ini.

Tabel 2 Jumlah Penduduk Provinsi Lampung Beradasarkan Asal Suku Bangsa Tahun 2010

\begin{tabular}{|c|l|r|r|}
\hline No & \multicolumn{1}{|c|}{ Asal Suku Bangsa } & \multicolumn{1}{c|}{ Jumlah } & \multicolumn{1}{c|}{ Persen } \\
\hline 1 & Aceh & 2816 & 0.04 \\
\hline 2 & Batak & 52311 & 0.69 \\
\hline 3 & Nias & 465 & 0.01 \\
\hline 4 & Melayu & 18175 & 0.24 \\
\hline 5 & Minangkabau & 1633 & 0.92 \\
\hline 6 & Jambi & 409151 & 0.02 \\
\hline 7 & Sumsel & 1028190 & 5.40 \\
\hline 8 & Lampung & 30579 & 13.56 \\
\hline 9 & Sumatra Asal Lainnya & 9621 & 0.40 \\
\hline 10 & Betawi & 172403 & 0.13 \\
\hline 11 & Banten & 728684 & 2.27 \\
\hline 12 & Sunda & 4856924 & 9.61 \\
\hline 13 & Jawa & 8406 & 0.06 \\
\hline 14 & Cirebon & 6156 & 0.11 \\
\hline 15 & Madura & 104810 & 1.38 \\
\hline 16 & Bali & 185 & 0.00 \\
\hline 17 & Sasak & 518 & 0.01 \\
\hline 18 & NTB & 1235 & 0.02 \\
\hline 19 & Ntt & 538 & 0.01 \\
\hline 20 & Dayak & 411 & 0.01 \\
\hline 21 & Banjar & 21054 & 0.05 \\
\hline 22 & Kalimantan Lain & & 0.01 \\
\hline 23 & Makasar & 0.28 \\
\hline 24 & Bugis & \\
\hline & & & \\
\hline
\end{tabular}




\begin{tabular}{|r|l|r|r|}
\hline 25 & Minahasa & 948 & 0.01 \\
\hline 26 & Gorontalo & 144 & 0.00 \\
\hline 27 & Sulawesi Lainnya & 7754 & 0.10 \\
\hline 28 & Maluku & 1585 & 0.02 \\
\hline 29 & Papua & 2215 & 0.03 \\
\hline 30 & Cina & 39979 & 0.53 \\
\hline 31 & Asing/Luar Negeri & 1157 & 0.02 \\
\hline & Jumlah & 7581948 & 100.00 \\
\hline
\end{tabular}

Sumber: BPS, 2011.

Data tersebut cukup menarik karena justru etnis asli tidak menjadi mayoritas penduduk didaerahnya. Akan tetapi, jika melihat sejarah redistribusi penduduk di Indonesia, realitas itu dapat dipahami. Provinsi Lampung merupakan daerah yang pertama kali menjadi tujuan migrasi (transmigrasi) penduduk dari Jawa ke luar Jawa. Transmigrasi ke Lampung terbagi menjadi dua periode yaitu sebelum kemerdekaan dan setelah kemerdekaan Indonesia. Pada tahap pertama, program transmigrasi penduduk dari Jawa ke Lampung dinamakan kolonisasi yang dimulai pada 1905 oleh Pemerintah Hindia Belanda (Andrews, 1979:90).Gelombang pertama kolonisasi itu berasal dari wilayah Bagelan (sebuah daerah di Keresidenan Kedu (saat ini daerah Bagelen sebagai sebuah wilayah kecamatan di Kabupaten Temanggung, Jawa Tengah). Program transmigrasi (kolonisasi) oleh Hindia Belanda ke Provinsi Lampung terbagi menjadi empat tahapyang total sebanyak 189.938 orang. Perincian tersebut disajikan dalam tabel di bawah ini.

Tabel 3 Jumlah Peserta Transmigrasi Periode 1905-1941 ke Provinsi Lampung

\begin{tabular}{llc}
\hline \multicolumn{3}{c}{ Jumlah Peserta Transmigrasi 1905-1941 } \\
\hline Periode & Jumlah & Tahap Program \\
\hline $1905-11$ & 6.500 & Percobaan \\
$1912-22$ & 16.838 & Dibiayai pinjaman bank \\
$1923-31$ & 4.000 & Dibiayai pinjaman bank \\
$1932-41$ & 162.600 & sistem bawon \\
\hline Jumlah & 189.938 & \\
\hline
\end{tabular}


Sumber: Colin MacAndrews dan Rahardjo, 1979:93.

Tahap kedua, pemerintah Indonesia membuat Program Transmigrasi Nasional yang dimulai 1950. Pemindahan jumlah penduduk ke Lampung setelah Indonesia merdeka hingga 1974 berjumlah 597.926 orang. Dengan demikian, keseluruhan penduduk yang bertransmigrasi melalui program pemerintah (colonial Belanda dan Republik Indonesia) sejak 1905 hingga 1974 berjumlah 787.864 orang.

Untuk menambah rasa nyaman para transmigran di daerah tujuan, para kolonis berinisiasi memberi namatempat tinggal baru mereka di daerah tujuan migrasi (Lampung) dengan nama wilayah yang mereka tinggali di Jawa. Karena itulah, banyak nama daerah di Lampung yang sama dengan nama daerah di Pulau Jawa, seperti Pring Sewu, Banjarjo, Pekalongan, Way Jepara, Bagelen dan sebagainya. Para transmigran membangun kampung pertama kali bernama Bagelen yang saat ini wilayah tersebut merupakan salah satu desa di kecamatan Gedong TataanKabupaten Pesawaran(https://tirto.id/jejak-para-transmigranjawa-di-lampung-cidw diakes pada 21/05/2017).

Selain itu, pengelolaan lingkungan sosial dan politik di daerah tujuan juga disesuaikan dengan pengelolaan atau birokrasi di Jawa, seperti dalam struktur pemerintahan dikenal adanya kamituwodan lurah yang berlainan dengan struktur pemerintahan masyarakat (lokal) sekitarnya yang merupakan masyarakat adat.Hal inilah yang menjadi cikal bakal eksistensi dan tumbuh suburnya kebudayaan Jawa di Lampung. Kebudayaan Jawa tersebut hingga saat ini masih banyak ditemui di Lampung. Hal ini juga menunjukkan bahwa budaya Lampung terkikis dan tergeser oleh budaya Jawa. Salah satunya adalah penggunaan bahasa Jawa. Berdasarkan SP 2010, sebanyak 3.791 .368 orang di Lampung menggunakan bahasa Jawa. Jumlah penutur bahasa Jawa tersebut merupakan hasil dari migrasi penduduk dari Jawa ke Lampung sejak awal tahun 1900-an.

Selain transmigrasi yang diselenggarakan pemerintah, baik ketika masih dijajah Belanda maupun setelah Indonesia merdeka, ada pula penduduk yang bertransmigrasi secara swakarsa dan sudah barang tentu swadana. Dalam teori 
migrasi need and stress theory, penduduk akan bermigrasi permanen (lebih dari enam bulan) jika berbagai tekanan, baik tekanan ekonomi, sosial, maupun psikologis di daerah asal sudah di atas batas toleransi. Selain faktor di daerah asal, berbagai daya tarik di daerah tujuan juga akan menentukan seseorang bermigrasi. Semakin banyak atau besar informasi positif yang ada di daerah tujuan, maka penduduk akan semakin menuju ke daerah tujuan tersebut (Mantra, 2000). Dalam konteks transmigrasi ke Lampung, selain adanya program transmigrasi yang diselenggarakan oleh pemerintah, juga banyak penduduk yang bermigrasi secara swakarsa.

\section{Simpulan}

Berdasarkan hasil analisis data di atas, dapat disampaikan beberapa kesimpulan. Pertama, penutur bahasa Jawa di Provinsi Lampung mendominasi jumlah penutur bahasa-bahasa yang dipergunakan dalam komunikasi sehari-hari di Lampung yang mencapai 55,32 persen yang lebih dari empat kali lipat penutur bahasa Lampung. Dominasi ini, menunjukkan perluasan masyarakat bahasa Jawa tidak hanya di masyarakat asal bahasa Jawa, di Jawa Tengah dan Jawa Timur ajan tetapi juga sudah merambah ke luar dan sangat dominan. Walau demikian, kehidupan antarpenutur bahasa yang ada di sana tetap tidak ada gesekan sosial yang bersumber dari pemakaian bahasa sehari-hari. Bahkan antarpenutur bahasa saling berusaha tahu dan mempelajari serta menggunakan bahasa yang lain di antara mereka.

Kedua, jumlah penduduk Provinsi Lampung yang berasal dari suku Lampung tampak lebih setia menggunakan bahasa Lampung dalam komunikasi sehari-hari. Hal ini dapat dibuktikan melalui data penduduk beretnis Lampung yang menggunakan bahasa Lampung dalam komunikasi sehari-hari lebih tinggi persentasenya daripada etnis Jawa. Baik penduduk Lampung yang bertnis Lampung maupun menggunakan bahasa Lampung dalam komunikasi seharihari dalam kisaran angka yang sama, yakni 13 persen (etnis Lampung di Provinsi Lampung sebesar 13,56 persen, sedangkan penutur bahasa lain (baca: Lampung) sebesar 13,66 persen). 
Ketiga, ekspansi masyarakat bahasa Jawa di Lampung merupakan proses panjang yang dimulai sejak awal abad 20 (1905) oleh pemerintah Hindia Belanda karena untuk kepentingan suplai tenaga kerja perkebunan di Lampung. Karena langkah Belanda merupakan rintisan redistribusi penduduk dari daerah sangat padat penduduk (Jawa) ke luar Jawa, maka pada masa kemerdekaan pemerintah Indonesia meneruskan program tersebut. Kolonisasi masyarakat bahasa Jawa paling sukses dalam sejarah hingga saat ini adalah kolonisasi masyarakat Jawa di Lampung.

\section{Daftar Pustaka}

Abas, Husein. 1982. "Bahasa Melayu sebagai Bahasa Ilmu Pengetahuan Moderen dan Komunikasi Luas di Asia Tenggara: Suatu Jastifikasi Statistik", dalam Harimurti Kridalaksana dan Anton M Moeliono ed., Pelangi Bahasa: Kumpulan Esai Dipersembahkan kepada Prof.Dr.J.W.M.Verhaar,S.J. Jakarta: Bhratara Karya Aksara, hlm 273289.

Biro Pusat Statistik. 2011. .Penduduk Indonesia Hasil Sensus Penduduk 2010. Jakarta: BPS.

--------. 2011. Kewarganegaraan, Suku Bangsa, Agama dan Bahasa Seharihari Penduduk Indonesia: Hasil Sensus Penduduk 2010. Jakarta: BPS.

Borbely, Anna. 2000. "The Process and the Factors of Language Shift and Maintenance: A Sociolinguistics Research in the Romanian Minority in Hungary". http://e-lib.rss.cz

Borin, Lars. 2009. Linguistic resources for the languages of the world. Språkbanken, Dept. of Swedish Language, University of Gothenburg GF summer school, 26 August.

Bujono, Bambang dan Leila S Chudori, ed. 2008. Bahasa: Kumpulan Tulisan di Majalah Tempo. Jakarta: Pusat Data dan Analisa TEMPO.

Kesuma, Tri Mastoyo Jati. 2007. Pengantar (Metode) Penelitian Bahasa. Yogyakarta: Carasvatibooks.

Kushartanti, Untung Yuwono, dan Multamia RMT Lauder. 2005. Pesona Bahasa: Langkah Awal Memahami Linguistik. Jakarta: Gramedia Pustaka Utama.

Mantra, Ida Bagoes. 2015. Demografi Umum, Cetakan XVII. Yogyakarta: Pustaka Pelajar. 
Mujid F Amin dan Suyanto. 2017. "Pergeseran dan Pemertahanan Bahasa Ibu Dalam Ranah Rumah Tangga Migran di Kota Semarang". Nusa, Vol. 12 No. 1, hal. 34-41.

Musgrave, Simon and John Hajek. 2010. "Sudanese Languages in Melbourne: Linguistic Demography and Language Maintenance". Selected Papers from the 2009 Conference of the Australian Linguistic Society, edited by Yvonne Treis \& Rik De Busser. http://www.als.asn.au.

Nababan, PWJ. 1985. "Bilingualism in Indonesia : Ethnic Language Maintenance and the Spread of the National Language", Southeast Asian Journal of Social Science, No.XIII-1, 1-17.

1984. Sosiolinguistik: Suatu Pengantar. Jakarta: Gramedia.

Samuel, Jerome. 2008. Kasus Ajaib Bahasa Indonesia: Pemoderenan Kosakata dan Politik Peristilahan. Penerjemah Dhani Saraswati Wardhani. Jakarta: KPG (Kepustakaan Populer Gramedia).

Sudaryanto. 1988. Metode Linguistik Bagian Kedua: Metode dan Aneka Teknik Pengumpulan Data. Yogyakarta: Gadjah Mada University Press.

Suyanto. 2011. Dinamika Jumlah Penutur Bahasa Indonesia :Studi Data Sensus Penduduk 1980. Kajian Sastra, Vol. 35 No. 1, hal. 55-67. 